\title{
THE CHINESE, THE VOC AND THE OPIUM
}

Currently, about 40 million Chinese live permanently outside China in 130 countries, most of them in Southeast Asia (Nanyang). This phenomenon will be discussed later in more detail (ch. 25). Here some of its early characteristics in the East Indies will be highlighted because it was in hindsight the "role model" for many later developments of the Western Opium Problem in Asia.

The confrontation between the Chinese and the VOC has so much practical and symbolic value for our history that also for the early phase of it, a detailed explanation of its role can be fruitful. The Chinese operated in the East Indies as traders and peasants before the Dutch came. After the arrival of the Dutch, they soon became their main trading partners and later also the important opium farmers. It became a 300-year confrontation between Western and Eastern foreigners, between masters and servants, but also between murderers and victims.

Two hundred years after the first Dutch-Chinese meetings in the East Indies, the British Empire decided to conquer China through bombardment with opium, followed by gunboats and cannonballs. The Opium Problem was transformed into a confrontation between West and East on a world scale. One can, therefore, ask whether this was foreshadowed by the earlier Dutch-Chinese relationship? Let us examine the characteristics of it in this chapter.

Certainly, it is not the first relationship between a Western power and Chinese. The Portuguese were allowed to settle in Macao (Macau) in 1557 with a few people, establishing a few buildings to repair their ships. Slowly some trade developed, which was immediately of a peculiar kind: Chinese were caught and sold to Lisbon as slaves; they were highly desired in Portugal, much more than Arabs or blacks. Although this trade only lasted a few decades before it was forbidden by both the Chinese and Portuguese authorities (1595), it was a peculiar first relationship between a Western country and China. It is also the only occasion of this kind. That was not the case with mass murder in the East Indies. ${ }^{1}$

\footnotetext{
1 Alas, it became a strange habit to compare the hatred and massacres of Chinese with the Jewish ones by using words such as "diaspora", "pogrom", etc. One has to realize that it
} 


\section{Murder in Batavia}

Just before Mossel's arrival in Batavia, terrible things happened there: the Dutch foreigners under the leadership of their highest officials like Van Imhoff and Valckenier massacred the majority of the unarmed Chinese foreigners. ${ }^{2}$ This has been ignored, at least in Southeast Asian history. The 'Chinese Massacre of 1740' with about 20,000 mostly Chinese victims is not the only Dutch massacre of this magnitude (see Banda Massacre). It is certainly the first and largest (Dutch) colonial act of Sinophobic violence. Before analyzing this question, we need a few facts.

Around 1740 about 25,000 people (including slaves) lived in Batavia and the surrounding countryside, with the Dutch forming only a small minority (not even 10\%) and the Chinese proper (excluding their servants and/or illicit emigrants) $50 \%$. In the countryside corrupt Dutch sheriffs created a "Wild West" lifestyle for the Chinese peasants. As the Chinese domination of the sugar market declined, mass poverty, unemployment and ruin followed. The rural Chinese protested and, in the end, revolted in 1740 under classic banners like "to choose the right day and the right moment" or "follow the righteous of olden times". ${ }^{3}$

is a typically Western way of thinking, overloaded as it is by guilt feelings for the murder of Jews. See, for instance, L. Pan, p. 128-153 or J. Blussé (1986) who even uses 'holocaust' (p. 94). Chinese and Jews, however, have nothing to do with each other except some "superficial" characteristics: tragic things like the periodical massacres by "white" torturers and their helpers or their perception as "non-conformists", rich and merchants. The classic mistake is to introduce here ethnic characteristics, but a few moments of reflection on the phenomenon "Chinese Jews/ Jewish Chinese" is enough to cure oneself of it. One can also read H. Derks (2004), chapter 6.

2 It is strange that in GM, $\mathrm{X}$ there are only a very few indications that a Chinese massacre ever happened. The last message from Valckenier dates from 31-3-1740 (p. 461-493) and than nothing until a few lines on 31-10-1740 about 'a substantial rebellion and brutal venture against the Company' (p. 494). The next message of half a page dates from the first of December. It is a request from the VOC chief of Onrust (the island off the coast of Batavia, the VOC's ship-building yard) to his carpenters to return to the island. They apparently assisted the military to combat the Chinese guerrillas. The reason for the silence: the clerks, who wrote the GMs, had to fight as well!

${ }^{3}$ For the following E. M. Jacobs, passim; W. Remmelink, p. 125 ff.; E. Vanvugt (1985), p. 78 ff.; D. Hall, p. 311 ff.; J. Blussé (1986), p. 73-97; N. Randeraad (ed.), p. 23 ff. These rural Chinese cannot be qualified as 'vagabond Chinese' as Vanvugt writes or 'bandits' (Remmelink). Apart from several interesting quotations, the latter mitigates in an untenable way the whole question of the massacre as something which had already happened in Manila six times (Id., p. 96). The relationship Chinese-Spaniards in Manila was much more complicated, with three different Chinese parties (the "pirate-king" Lim Hong who attacked the Spaniards from the seaside as a kind of liberation guerrilla, the Chinese from China who also chased Lim Hong, the Chinese who worked in the city of Manila under bad 




Ill. 16. The Dutch Massacre of the Chinese, October 8th, 1740

Source: C. Boxer (1977) p. 71. Some 12,000 - 20,000 Chinese were killed in Batavia alone; all the houses and shops of Chinese were looted and mostly burned. In the countryside many suffered the same fate 'as a matter of precaution'.

The first phase of the massacre was triggered by this revolt of the desperate, rural Chinese poor. Their urban masters, Chinese captains and officers and Dutch alike, did not want to improve their situation, but killed many and captured others to transport them to Cape of Good Hope or Ceylon. The rumor that they would be thrown overboard during the trip aggravated their anger. They started to attack the city gates, but again many were killed.

The second phase started not only with the easy defeat of these rural poor, but also with the decision of Governor-General Valckenier to attack the urban Chinese. The second highest Dutch official, Van Imhoff, urged the elimination of only the poorly armed urban Chinese. This last plan was carried out, but during this action a few buildings were set on fire by unknown people. This panicked the European population, and assisted by sailors, slaves and servants, they started a hysterical massacre that last-

circumstances and revolted three times $(1602,1662,1686)$. There was never a massacre of the magnitude of "Batavia", let alone under the same circumstances. See A. McCoy, E. de Jesus (ed.). 
ed three days in which Valckenier personally ordered the killing of Chinese prisoners, throwing the sick out of the hospitals, etc. Van Imhoff, the next Governor-General, contributed to this lethal festival by paying a premium to all who could throw a decapitated head of a Chinese person out of the city. It ended by setting the whole Chinese quarter on fire. Definitely 12,000 Chinese were killed; all the houses and shops of Chinese were looted and mostly burned. There are several personal testimonies (1751) of people who plundered and murdered like the German carpenter Georg Schwartz, sent by his boss:

As I knew that my Chinese neighbor had a fat pig, I intended to take it away ... When my boss ... saw this, he slapped me and told me to kill the Chinese first and then to plunder. I, therefore, took a rice-pounder and with it beat to death my neighbor with whom I so often had drunk and dined'. That was not all; Schwartz discovered a pistol, went outside 'and killed everybody who I met ... I had grown so accustomed to this, that it was the same to me whether I killed a dog or a Chinese. ${ }^{4}$

Outside Batavia, in Semarang, the Dutch leader Visscher considered 'massacring all able-bodied Chinese in the district' as a matter of 'precaution'. In a lethal game of divide and rule, he urged the Susuhunan to fix this job. ${ }^{5}$ The Protestant clergyman, Wagardus, declared in the commemorating service after the massacre that God's help was necessary 'to crush this Chinese revolt'. This help was not very effective: what was left over of the rural Chinese initiated a kind of guerrilla war which was so successful that a Javanese ruler of Mataram publicly supported it. The Dutch took several years to suppress this new revolt. In West Java, Bantĕn (Bantam), the Dutch faced a new war, and so on.

Not every Dutchman was convinced of the need for all this. They lived far away in the Netherlands without much communication. Still, a poet at the time expressed his anger in the following lines ${ }^{6}$ :

Look this Chinese, his wife and kin, humbly kneeled, a disaster cannot be avoided by him. Look how they are all killed,

4 Quoted in J. Blussé (1986), p. 95 who suggests the scum of the VOC is guilty, here a German carpenter-servant (Holocaust!). He mentions nothing about the behavior of the VOC leadership. Not so Remmelink, who later rightly stresses 'that the massacre in Batavia had not been a mob action, but an act of policy' (W. Remmelink, p. 128).

5 W. Remmelink, p. 127, 128.

6 C. Boxer (1977), p. 96; my translation. 
heart and head peeled,

while nobody knows their guilt.

\section{Birth of a Chinese Hate?}

Historians counteracted these cruelties by stating in all seriousness that the VOC people 'after 1700 acted much less aggressively than in the previous period', which was 'not due to their [better] skills..' 7 The longest-term effect is, anyway, that even after the decolonization, "Chinese hate" was so thoroughly engrained in this ex-colonial society that even after 1949, severe anti-Chinese massacres were "successfully" organized several times in Indonesia. This serious crime directly contributed to a new war with Mataram (1741, etc.), was an impulse stimulating the great revolt of Bantĕn against the VOC (1748, etc.), but also the decline of the VOC itself: the trade with China became too strongly blocked, while it could not be based on such an aggressive distrust and discrimination.

Without doubt the junk trade to Batavia was dealt a staggering blow by the tragic occurrences of 1740 . A large part of the infrastructure and the organization of the trade in Batavia simply disappeared because many of the Chinese brokers and key figures had been either killed or banished ... the junk trade shrank within a few decades to a shadow of its former self. ${ }^{8}$

These are the direct effects of the massacre (see further below), but why did it happen at that time? I can find three reasons: the existence of a broadly supported anti-Chinese racism, a typical urban-rural antagonism in Batavia, and the very limited ability of the VOC leadership to understand and master the situation.

The main sources of sinophobia were mostly hidden in Pandora's Box: Dutch positive racism ("Chinese are a degenerated race"), Dutch negative racism (bad conscience about their own murder practice and perpetrator's behavior standardly followed by a "but" ... "they" provoked "us" in some way or other), Dutch xenophobia ("we" do not like strangers), Dutch Protestant religious legitimation ("they" are pagans; God is on our side) and Dutch economic interest ("they" are "our" competitor; "they" are "rich" and occupy key economic positions).

7 F. Gaastra (1991), p. 97. It is a strange opinion relative to the cruel practices described here and wars in the 18th-century. The only relevance one could discover behind it is that the personal violence against their own soldiers and sailors seemed to be less in the 18th

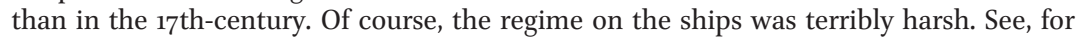
instance, Governor-General Both's letter 13 in Both, vol. 2, p. 268-271.

8 J. Blussé (1986), p. 139, 140. 
These sources all claimed that the Dutch leadership thought it necessary from a real-political point of view to teach "them" a lesson "they" will never forget. It is a message not so much to the alleged "enemy", but to a substantial proportion of Dutch supporters indoctrinated by the same doctrines and willing to react. In this case Valckenier and Van Imhoff had opened Pandora's Box.

The interaction with Europe is obvious. All these sources have a European background, and memories were still "fresh" after the terrible religious and economic European wars of the sixteenth and seventeenth centuries in which sometimes one-third of a population of millions was eliminated. ${ }^{9}$ The application to the Chinese and the combination are, of course, a colonial one and unknown in the West (although the returning colonialists brought many of these ideas back home). One may suppose that once the European leadership ventured abroad, these prejudices were activated much more quickly when arriving in a fully unknown, strange and tropical world.

Beginning with the soldier-hirelings from these wars, the scum of the European nations formed the large majority of people engaged in the colonial ventures. ${ }^{10}$ The pious Governor-General J. P. Coen is the Dutch example par excellence of these terrifying figures or, in this case, Valckenier or Van Imhoff'1; the Portuguese, Spaniards or English have many examples as well. The mediocre leaders of Western colonizers also showed an unprecedented cruelty against new environments, people as well as nature.

That cannot be rationalized with an appeal to the primitive peoples, who are "by nature" barbarous, or something like "the spirit of the time" (not even: 'the European spirit'). The massacre in question was, of course, a direct consequence of the Dutch colonial exploitation in which harsh attacks (bullets against knives) alternate with rigorous divide and rule games played between the different population groups inside and outside

9 For detailed analyzes of the forms of racism in Western societies, see H. Derks (2004).

10 F. Gaastra (1991), p. $81 \mathrm{ff}$. This was a serious problem from the beginning also relative to the first European women who were imported in the Moluccas. There were many complaints about their licentiousness, etc. See Both, vol. 1, p. 103 ff. Already in 1612 the first Governor-General, Both, issued the cruelest sentences to counteract their behavior. It helped only for a short while.

11 The latter is probably even a "better villain" than Valckenier, because he manipulated the VOC Directors in Amsterdam and the lawsuit so long that one started to believe that Valckenier was the only one guilty of the murder of innocent Chinese. See C. Boxer (1977), p. 96. 
Batavia and Java. For the Dutch it is a routine case, although the one is much better able to play this game than the other. There is the impression that VOC employees generally belonged to the scum of the European nations and, therefore, relied on violence too quickly, even more than the English did.

This massacre fractured social relations, diminished the workforce and many services formerly provided by Chinese, but it also immediately disrupted the junk trade with China. Merchants from China had lost an important market, and their trading partners for all kinds of commercial ventures elsewhere in Southeast Asia.

When they first arrived (1619), the Dutch were confronted with 400 Chinese merchants, but also with the so-called Mardijkers, ex-slaves of the Portuguese who had a kind of free status. Under the leadership of J. P. Coen, a rigorous population policy was carried out. As given above, he asked for as many slaves as he could get. Generally, people did not live very long in an unhealthy, marshy place like Batavia; "new blood" had to be constantly imported. They also activated the import of new Chinese groups and accepted that rich Chinese would also import Chinese from China. This created the "coolie problem" in mines and plantations and increased the power base of a Chinese elite.

Under Dutch leadership, multicultural coastal settlements developed as islands in indigenous societies which the Chinese dominated, at least in numbers. In Batavia around 1699, they formed $39 \%$ of the population (the Dutch 19\%) of nearly ten thousand inhabitants, representatives of all sorts of indigenous tribes and parts of Asia. On the eve of the massacre, the Chinese were $58 \%$ against the Dutch $18 \%$ of a total population of 7,233 (excluding slaves). That figure referred to inside Batavia and not the countryside.

In addition, the Chinese had trade relations with the Dutch in many respects, and the Dutch considered them unarmed competitors as well. Because the Chinese were accustomed to the same "maritime business" as the Dutch, they were readily seen as partners in financial and other "maritime business" co-operations. Most indigenous tribes or larger social formations were generally qualified as "lazy" and in a racial sense more "degenerated" than the Chinese.

Even an Englishman of the stature of Raffles copied these dangerous and ridiculous typical Western perceptions when he wrote: 
The Chinese ... are to a high degree more intelligent, more laborious and more luxurious. They are the life and soul of the commerce of the country. ${ }^{12}$

And regarding the Malays, for instance,

that when he has rice, nothing will induce him to work. Accustomed to wear arms from his infancy ... he is the most correctly polite of all savages ... But with all his forbearance, he is feelingly alive to insult; submits with a bad grace to the forms to which, in a civilized life, he finds himself obliged to conform; and when these are ... numerous or enforced ... he flies to the woods, where ... he feels he is free. ${ }^{13}$

It looks like a positive discrimination of the Chinese. We become suspicious because this man, who had rather intelligent explanations for all and everything in his history of Java, did not comment much on the Dutch mass murder of Chinese and the subsequent wars. He only concluded that the Chinese 'are considered to have much decreased'. The Malays were degraded thanks to the exploitation of the Dutch, the Chinese or the Arabs, as well as their own rulers. The British, however, are the Europeans who were best suited to transform Malays into good Englishmen, if that suited the British interests.

Raffles writes about other foreigners living in the archipelago in his History that 'the natives of the Coromandel and Malabar coast ... usually termed Moors' once were numerous, but their number has considerably decreased 'since the establishment of the Dutch monopoly and the absolute extinction of the native trade with India, which ... was once very extensive.'

In his Memoir, however, he calls the Arabs 'mere drones, useless and idle consumers of the produce of the ground', inculcating the most intolerant bigotry. The Islamic religion was nothing but a 'robber-religion' against which only the propagation of Christianity could be helpful. He expressed in the same wave of anger his astonishment that among all of the tribes in the realm ('slaves into the hands of the English') not a single one could be converted to Christianity; all of them became Muslim, 'and despise and hate their masters as infidels.' ${ }^{14}$

Indigenous people like the Buginese and other tribes in the East Indies archipelago, who were at least as clever and skilled at sea as the Dutch, were seen by the Dutch and English only as pirates, to be eliminated

\footnotetext{
12 Th. Raffles, vol. 1, p. 75 .

13 Quoted from Raffles' Memoir of the Life and Public Services of Sir Thomas Stamford Raffles (London 1830, 1835) by S. Alatas, p. 28.

14 Idem, p. 30. These are still very popular creeds on both sides of the Atlantic.
} 
wholesale and as soon as possible. When this proved impossible, they could always be recruited for the armed forces for 'good money', as the Dutch used Japanese samurai earlier as killing machines in Banda and elsewhere.

When these people directly acted against Raffles' or British interests, the judgments immediately change into the strongest accusations based on "facts" which he knew could not be true. Thus, without any qualification, he talks about how 'The' Chinese were only 'the agents of the Dutch' from the beginning, acquiring the entire monopoly of opium revenue farms and government contracts. ${ }^{15}$ Therefore, the British government was warned against the Chinese:

Although the Chinese, as being the most diligent and industrious settlers, should be the most useful, they have, on the contrary, become a very dangerous people, and are to be labelled a pest for the country; and there appears to be no radical cure for this evil but their extermination from the interior, a measure which cannot now be effected. ${ }^{16}$

Here, in a statement of an intelligent, learned, leading Western politician - a white elephant anyway - the Chinese hate is expressed by using the verdict of wholesale extermination in an even more stringent way than was the case of the Buginese.

This must be the reason why Raffles failed in his job as historian in the case of the Massacre of 1740 . He also paved the way for further acts of lethal violence against "The Chinese", mobilizing enemies of these enemies according to the classical divide-and-rule maxims. Raffles continues his philippic with, among others:

It is, therefore, of the greatest importance to be on our guard against this pernicious and increasing influence, which preys on the very vitals of the country, draining and exhausting it for the benefit of China. In all the Malay states, the Chinese have made every effort to get the collecting of the port duties into their hands, and this has generally proved the ruin of the trade ... This ascendancy of the Chinese ... should be cautiously guarded against and restrained, and this perhaps cannot be better done than by bringing forward the native population of Malays and Javanese ...17

$15 \mathrm{M}$. Adas writes that the Dutch deprived the inland court centers of their trading outlets to the sea and, therefore, of the main sources of revenue. 'The remaining local and inland trade was sizable, but it gradually fell into the hands of the Chinese, who served both the Javanese and Dutch as middlemen, tax farmers, and landlords' (p. 7).

16 Th. Raffles, Memoir, p. 29.

17 Idem, p. 30. Raffles should be seen as a true pathological mind; a judgment which seems unavoidable after reading the extensive quotation in S. Alatas (p. 32) about Raffles' description of the cannibalism of the Bataks. It is too obscene to quote here, but after his 


\section{Chinese as Victims}

Thanks to the occupation and violent repression by the Dutch and English, a hierarchy of norms, values and judgments was established based, of course, on European arms and cultural traditions. Batavia was a copy of a Dutch seventeenth-century city with canals, etc. as was Paramaribo in the "West Indies" and all Dutch colonial settlements in between. From the start, the foreigners violently impressed their Christian culture on the inhabitants of the archipelago, as happened with the Banda islands and others.

One consequence of this whole constellation was that the overseas Chinese seldom or never became enslaved by the Europeans, as was the case with people from India, Java or other East Indies islands, let alone the "blacks of Africa". The Chinese remained "free" but servants, never equals. As such, they were still a "good cargo", notwithstanding the fact that they were pagans and very uncivilized, dirty folk to the barbarians and 'foreign devils' from Europe.

Small wonder, as they were imported as "coolies" under the dirtiest circumstances and in order to do the dirtiest work. The most well-known example is the miners and railway laborers in 19th-century USA, but they were already used in the $17^{\text {th- }}$ and 18 th-century Dutch tin mines on Banca and Malacca or on plantations, and they were given opium to consume to keep them working (see ch. 16).

The Chinese already had a Southeast Asian history in which they were not victims in the given sense. ${ }^{18}$ They lived in some coastal settlements in the East Indies long before the Europeans arrived (1511). They never had any imperialistic motives, and no traces of discrimination or lethal actions against them are known from that time. Ethnic differences and related cultural differences remained alive. Of course, they were mostly economically integrated, but in a social or cultural sense, there was apparently not much need to become acclimated.

extermination verdict of the Chinese, etc., this positive perception of this habit should be called pathological indeed.

18 See further ch. 25. There are rather irrelevant theories about some resident group of Tang Chinese in Java, but that cannot be our concern here. See C. Menghong, p. 14. See also Th. Raffles, vol. 1, p. $74 \mathrm{ff}$. It is enough for us to know that as early as the second half of the 12th-century, a Chinese source mentioned the commercial prosperity of Java and 13thcentury sources talked about the many and diversified merchandise handled in the old Buddhist kingdom of Çrivijaya (at the site of the later Palembang). They came from the West (Persia, Arabia, etc.), the East (China) and the archipelago itself. There was no opium among the goods. See M. Meilink-Roelofsz, chapter 1; J. Wills, chapter 1. 
The Chinese lived in small groups, busy with mining or agriculture, but mainly oriented towards the sea. They were accepted as important mediators to the outside world. In trade and related industrial work they also maintained the communication with China in several ways and supported the junk trade in all respects, from money exchange to ship reparation. ${ }^{19}$

Since their emigration from China, they had established settlements which could later form a network allowing the exchange of labor, work, capital, goods, etc. The Chinese functioned well in a rather vital Asiatic commercial world centered around the Malacca (Melaka) peninsula, including parts of the East Indies like Bantam in the south or the Moluccas in the east. More precisely, in the existing lively trade networks of the Javanese or Moluccans, the Chinese helped to extend these networks in the direction of China and settlements with overseas Chinese and to activate the relations between the regions of the Indian Ocean and the China Seas.

Apart from the usual personal daily conflicts, problems with or against indigenous folk did not occur on any large scale. None of the parties had any intention to overrule the other. Cultural ties in Java remained selfevidently shallow in this situation: intermarriage existed but was not widespread outside the three large settlements of Batavia, Semarang and Surabaya. People descending from a mixture of Chinese and indigenous folk were so numerous that they received a special name, pernakans.

This relative mutual "living apart together" was still active when after a certain period the the Chinese undertook agricultural work in the surroundings of their settlements. When the Dutch arrived in Java, this was more or less the situation they found..$^{20}$

This relatively peaceful world was aggressively forced into the power schemes and trade aims of the Western nations. The VOC played a major role. Meilink-Roelofsz was one of the first to acknowledge this:

19 About the junk trade in the VOC era to Batavia, see in particular the excellent article of J. Blussé (1986), p. 97-155. Raffles stresses the annual return trips to China, but such trips from-say-Semarang to Canton and vice versa were difficult or could not be acocmplished within a year at the time.

20 For many details of the ambiguous Chinese-Dutch relations, see also J. Blussé (1986), chapter 5 or Idem (1989), a well-illustrated book without making serious attempts to destroy the usual prejudices. The early appearance of the Chinese is already mentioned in the remarkable J. Vleming, p. $1 \mathrm{ff}$. He used as source an article of W.P. Groeneveldt, the man responsible for the reconstruction of the opium business in the archipelago. See below. 


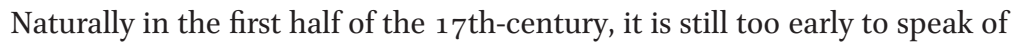
the Dutch ... politically dominated East Indies, but nevertheless, economically, the Company represented a power factor in the Indonesian Archipelago ... which seriously disturbed or even utterly destroyed various aspects of the native economy. ${ }^{21}$

The Dutch came to rule and exploit everybody else in an economic, social and cultural sense. They had a keen interest to exploit social and cultural differences among the "available populations". The wars they fought against Mataram and Bantĕn also had a negative effect on the daily life of the Chinese who came to live in and around Batavia. Still, for a long time indigenous people liked to deal with the Chinese, but not with VOC employees. The Banjarese people said that the Chinese "paid much more for the pepper and in addition they carry with them always much more interesting merchandise." 22

Notwithstanding this, the Chinese now became middlemen and therefore distrusted by many, Dutch and indigenous alike. They themselves started to demonstrate this behavior as well. For instance, when the sugar fields of the Chinese were destroyed time and again by Javanese warriors, and life became dangerous for them, they fled to the Company. But if the repression of the Dutch was too severe, the Chinese moved to Mataram or Bantĕn (Bantam) for protection and better living conditions.

However, things must be seen in perspective. From a Dutch point of view, their prejudices about the Chinese are closely related to their prejudices about the indigenous people: they were perceived as antagonists, but the inherent value judgments were fully Dutch: both the Chinese and Javanese had to became inimical to fit in the divide and rule game. During Vischer's visit to the Susuhunan (or "Sunan") in Semarang with his bloodthirsty request to eliminate all Chinese, he also informed him that in Batavia they were prepared somehow to come to terms with the 'good' Chinese:

In his answer the Sunan expressed his great surprise that the Chinese had had the assurance to revolt. For it was widely known by all leeward nations that the Chinese were like women, without any power of their own. They were only good for trading or managing toll-gates. Wherever they lived, they were supported by the Company, which allowed them to trade and become rich. Without the support of the Company they would not be able to maintain themselves because of their cowardice. ${ }^{23}$

\footnotetext{
21 A. Meilink-Roelofsz, p. 10, see also idem, p. $28 \mathrm{ff}, 40,174$.

22 GM VIII, p. 97 reported 5-12-1726.

23 W. Remmelink, p. 128.
} 
This Javanese leader apparently was not aware of his prejudice, but he and 'the whole of Java' was convinced that something miraculous had happened, now the Chinese and the Dutch were revolting, 'who were like two sides of the same coin': it was so inconceivable 'that this could only be a sign of God ... many seemed to believe that it spelled the end of the Company'. ${ }^{24}$ That was not far off the mark, but this Susuhunan could easily have found out how the Chinese fought together with the Javanese against the foreign intruders time and again.

The image of the two sides of a coin did have a ring of truth for the Chinese-Dutch cohabitation. They became to be more dependent on each other, but at the same time they became also more equal: the Chinese provided many services relative to the trade with the North, but also the daily food for the Dutch came from Chinese agricultural work in the country. It is, furthermore, a typical characteristic of repressive powers that they urge one-person leaderships (captains) of opposing groups. Not only as representative of the whole group, but also as an adequate means to suppress and control the subjects and antagonists. ${ }^{25}$

This kind of representation urged by a perpetrator is never trusted by the oppressed and perceived as a puppet of - in this case-the Dutch colonial government/VOC. That was also the case with the Chinese captain and his officers in Batavia, gathered in a true Chinese Council (Kong Koan): it was only accepted as long as the interests of the foreign occupier were served. The Chinese captain, killed in 1740, knew in his last moments the answer to whether such a representative institution of the weak in an aggressive perpetrator's setting could have any other function than to support the perpetrator's aims.

The method is: be an adviser to the perpetrators, but exert authoritarian power over the community in order to avoid new protests and revolts. ${ }^{26}$

24 Idem, p. 129.

25 One must, again, realize that this is a typically Western legalistic habit. The most well-known "institution" is the Judenrat (Jewish Council) installed everywhere by the Nazis in the occupied countries and in Germany itself. But see also the captain institutions in the Dutch West Indies (Dutch Guyana-Surinam). Blussé is too naive in his description of the case. In the Asian colonies the Dutch system of the "Kapitan China" was adopted elsewhere as well. See N. Tarling (ed.), vol. 2-1, p. 79.

26 C. Menghong provides much information about the work of this Chinese Council (Kong Koan) in the 19th-century, but has not the slightest idea about the meaning of the ambiguous political-moral position between a colonial repressive regime (illicit) and something like a Chinese community in a Western colony. She reproduces largely the Dutch perception and position in her description of the smooth functioning of the Kong Koan: 'As intermediary between the colonial government and the Chinese community ... 
The Dutch were interested only in division to sustain their minority rule: between town and country, between Chinese and indigenous, but also between the Chinese elite and the majority of Chinese lower class people. Therefore, they divided up the different groups into their own camps, quarters, housing blocks and so on within the classical grid-iron lay-out of all colonial settlements. ${ }^{27}$ We can be skeptical about the strong attempts to conserve traditional values, folklore and so on in such camps or quarters, while asking whether it is genuine Chinese, Javanese, etc. culture or a Pavlovian reaction to Western colonial demands for division and isolation, the results of the rigorous divide and rule game.

It is, therefore, not at all 'paradoxical' (Blussé), but quite logical that the Chinese in the countryside remained unprotected by their own cityofficers and were at the mercy of the Dutch sheriffs and commissaries. It was this Dutch behavior in creating mutual distrust which triggered a Chinese revolt and the massacre. It is not 'paradoxical' that the rural Chinese protesters in 1740 wrote to their urban colleagues that they were going to attack Batavia

in which city so few Dutchmen and so many Chinese live, and where nevertheless [the Dutch] dare to treat the Chinese so harshly and oppress them so unjustly, that it can no longer be tolerated. The Chinese nation is forced to unite and with all force declare war upon the Dutch. ${ }^{28}$

No oppressed people are trusted by the perpetrators: one day they will inevitably wreak revenge for their bad life. The Chinese were, of course, never trusted by the Dutch, notwithstanding their slow acceptance of the "Dutch" captains as even an honorable job for the Chinese elite and the substantial mutual advantages. From the quotation below it seems that they were mutually divided as well, longing for common action against a common enemy.

A Dutchmen, called an 'enlightened person', recalled the Roman Empire's administration as he advised his Governor-General in 1705:

Look at the example of the turbulent Chinese, who have been and remain subdued by the Tartars with a small force ... The Tartars keep only the army to themselves without giving the Chinese a say in these affairs, so that always a tight reign can be held on them during an emergency. ${ }^{29}$

on the one side.. direct rule over its [the Kong Koan's] subjects (sic!) and on the other side ... execution of the colonial instruction as careful as possible.'

27 For an analysis of these colonial city-systems see my (1986), p. 386-413.

28 Quoted by J. Blussé (1986), p. 94 from J.K.de Jonge a.o. (ed.), vol. 9, p. lvii.

29 Quoted by J. Blussé (1986), p. 88. 
How the Dutch applied quite different norms if Europeans or Chinese violated their laws is demonstrated in the following examples. ${ }^{30}$ Three Dutchmen were caught because of their violent behavior against Dutch citizens, but apparently also because of the discovery of 230 chests of smuggled opium, 'the owners of which could not be found .... These Dutchmen were punished by sending them back home. ${ }^{31}$

The comment on this report is interesting: it is a pity that Dutch 'false wage-earners' behave as cheaters, but it is shocking that 'wealthy gentlemen' are doing this. Only the latter can afford to buy such an expensive lot of opium, which could be sold for 67,056 rixdollars. The rich Dutch owner of the contraband was not found in the small Dutch community in which everybody knew everybody. From top to bottom of the Dutch community, people were involved in some form of corruption. However, there were at most twenty people who could pay that amount of twenty times the annual salary of a Governor-General! ${ }^{32}$

In the same report, however, there is a description of a Chinese who was caught in the act when forging coins:

... he is sentenced to death on the gallows after his right hand is amputated, but in the end this sentence is by us augmented, so that he must die through the fire in order to make it a deterrent. ${ }^{33}$

30 This is not only a Dutch custom but also, for example, a Portuguese one, as M. Meilink-Roelofsz, p. 127 shows. One may perceive this, therefore, in a much more general perspective. In the Portuguese-dominated settlements the higher ranks of nobility, civil rulers and priests 'fell outside civil jurisdiction'. The interference of clergymen in secular jurisdiction was detrimental as well. This apart from the "strangeness" of the mutual (licentiousness) behavior of these foreigners, let alone their criminal behavior as 'acts of violence and piracy against native shipping'. This was too often done by or under protection of 'captains of the forts' who could handle all possible cases largely independently of the colonial government or of the government in Portugal. In principle, this was not different among the Dutch, although some regulations were introduced gradually. But regarding Dutch force exerted against Chinese junks from 1620 onwards, see Idem, p. 238 or $253-256,264-268$ and so on.

31 What was to happen with them in Holland is not known: the usual punishment of the greedy Dutch authorities was to take all the money these people had saved during their stay in the "colony".

32 In that year, 1728 , there were no more than 1300 Dutch people living in Batavia. The very rich, who could afford this kind of smuggling, made up certainly less than $2 \%$. It is, anyway, the elite from which the members of the Amphioen Society were recruited 20 years later.

33 GM, VIII, p. 170 reported 31-1-1728. A similar case of smuggling opium from Bengal by Dutch people/ships is described Idem, p. 220, reported 8-12-1728. This concerned again 230 chests of opium; it led to 'freedom' for most; in Bengal 'nothing could be proved', and a few were deported. The same report (p. 221) mentions two Chinese who acted in a "criminal way". Now their sin was that they smuggled '6 picol of coffee'. They were rela- 
In an earlier situation other contradictory data about the VOC-Chinese relationship can be found. In 1708 the VOC had 1159 Chinese servants. ${ }^{34}$ A decade earlier there were serious conflicts with a group of $70-80$ Chinese in Semarang, including women and children. The majority of them were poor and newly arrived; there were also four chiefs [hoofden] who had lived there for some years as merchants. A Chinese lieutenant from Batavia, who was arrested for having debts, fled to this Semarang group. They all hoped to support the Susuhunan in his struggle with the VOC. This became a tragic failure: the prince delivered them all to the VOC. The Dutch broke them upon the wheel and killed 46 men of the group. ${ }^{35}$

The "in-between" position of the Chinese also had a quite different aspect. Around 1820 the discontent intensified among the Javanese nobility as well as among their peasants. One of the complaints was that the Dutch had taken full control of the many toll stations on central Java, originally a source of revenue for the indigenous regimes. ${ }^{36}$ Because they did not have the manpower to staff these stations and they were anxious to collect easy money, the Dutch farmed the tolls out to Chinese collectors. As long as they paid their agreed-upon quotas, the Chinese could do what they pleased. However, the original Chinese lessees in turn parceled out their toll stations to relatives or the highest bidder. They were always Chinese as well. The result was that the number of tolls was multiplied and the rates raised. Apparently after receiving complaints the Dutch "proprietors" of the tolls started to limit the contracts to one year. The Chinese toll farmers now reacted by squeezing all they could from the defenseless population before relinquishing their station to the next bidder. This squeezing often affected the Chinese merchants more than the Javanese. It was, of course, a new source of internal trouble among the Chinese. The Dutch source of all discontent remained, however, hidden behind a Chinese face.

tively lucky: their coffee was confiscated and they were severely flogged ('strengelijke laarsing').

34 GM, VI, p. 570: 952 in Bantam, 69 in Tandjongkait, 97 in Tanara and 41 in Pontang.

$35 \mathrm{GM}, \mathrm{V}$, p. 646 reported 8-12-1693. Of course, one can also point to very exceptional instances of heavy punishment of Dutchmen by the Dutch authorities. For instance, the act of Governor-General Zwaardekroon who in 1721 'had no fewer than 26 Company servants beheaded in one day for theft and smuggling' (D. Hall. p. 308).

36 For this example see M. Adas, p. 67. 
The example is not only chosen to demonstrate the possible effects of the middleman position. It also shows the mechanism of other Dutch farming systems, of which the opium one was the most important.

\section{Chinese and Early Opium Trade}

For centuries the Chinese junks traded in many kinds of products. Meilink-Roelofsz spotted in 1630 the following imported and exported "Chinese products": Brazil or dye wood, cloth, copper, foodstuffs, forest products, gold, handicrafts articles, iron pans, money, much pepper, lacquer, porcelain, salt, silk, spices, sugar, etc. However, no opium is mentioned under whatever name. At the end of the $15^{\text {th-century, a lively }}$ trade from Gujarat with China via Malacca was being carried out: main product was Gujarati cloth and 'very small quantities of the luxury products ... rosewater, opium, and incense, all typical products of the Near East ... ${ }^{37}$ This opium apparently came from Aden. ${ }^{38}$ This amount could never become a problem worth debating or researching.

There is another early report in 1610 about the opium trade to East Java (Grise near Surabaya). It was embedded in the much larger spice trade. The king of Surabaya had many junks himself, but the Chinese were intermediaries for the trade with West Java (Bantam) in rice, beans, sugar, fish, cattle, salt, cotton. From the West came many products like Indian fabrics, and opium. ${ }^{39}$ The Portuguese brought opium into the East Indies archipelago around this time. They bartered it for gold dust, gold coins and bezoar stones; in Pahang they probably could get rice and dye-woods for it. ${ }^{40}$ In a Dutch document of October 1620, opium is mentioned for the first time as 'a merchandise reserved for the Company only' while the import by others 'within the Jacarta jurisdiction' is prohibited. ${ }^{41}$

The first conclusion is again that trade in opium to and in the East Indies archipelago is very limited in quantity (if any) until about 166o. It was most likely used to smooth trade by presenting it as presents to indigenous rulers and their courts. Middle Eastern traders must have done this long before the Portuguese followed the trade movements in the 16th-

\footnotetext{
37 A. Meilink-Roelofsz, p. 64.

38 Idem, p. 69.

39 Idem, p. 271.

40 Idem, p. 165.

41 F. de Haan, vol. 4, p. 15. De Haan states that opium is mentioned for the first time in a document from 1667 , but that this must be a mistake: October 1620 is the relevant year.
} 
century. The Dutch gradually copied this at the beginning of the 17th-century and joined the opium business as well.

De Haan provides the reports of a certain Oluff Christiaansz (1700) about military expeditions into the interior of Java. The food they carried with them is largely destined for the VOC officials in Cheribon. Apart from coins they have:

... 12 bottles of sek [a strong sweet Spanish wine. F.d.H.], 4 bottles olive oil and 4 Dutch vinegar ... 10 pound Dutch butter ... and 4 pound amphioen to distribute here and there among the Javanese chiefs ...' De Haan adds that the VOC representative received opium 'to sell it during the trip for a good price in order to pay part of the cost ...' of the trip. ${ }^{42}$

Something must have been changed in the opium trade 22 years later. Then, according to another report 'opium appears to be the most important import article in Cheribon'. ${ }^{43}$ Many Dutch foreigners lived there. Did they use the drug despite the warnings of their bosses not to use opium? From whom did they got the amphioen? From the Chinese, who were the main leasers of the VOC opium according to the stories? Were there enough alternative distributors after the AS was established? Let's try to answer these difficult questions.

English and probably other European invaders also continued to compete with the Dutch to get a slice of the spice and other trade in the archipelago. The question is: whoever held the hegemony in the Strait region, around Malacca, could dominate the trade movements by means of passports and naked power. The Dutch won the game around the 166os, and everybody else had to stick to Dutch rules at least until about $175^{\circ}$. This was certainly the case for the Chinese junks, which were no match for European pirate/traders ships. The former looked for help to save them from the latter: The Chinese once complained about a Portuguese captain who threatened to destroy Chinese junks. The Dutch arrested this man and kept him in custody until a fortnight after the junks had disappeared

42 F. de Haan, vol. 2, p. 195 and note 4. Later (Idem, p. 470) the Dutch complained about the lazy Chiefs who smoked the opium which they had distributed themselves (also called madap, madat or medak and affion) instead of delivering coffee in time. They, furthermore, remarked in 1672 that they had had to fight 'peoples from Bantam mad from opium' (Idem, p. 752). Even a report of 1786 (Rolff) describes how soldiers had an income from amphioen and coffee (Idem, p. 614 note 5). For opium consumption as a result of presents from the Dutch "government" as early as 1636 , see F. de Haan, vol. 4, p. 14. The effect is given directly: the ruler of Djambi 'is stunned from eating amphioen' (1641). In 1657 opium is given as a present to the rulers in Mataram, but twenty years later a Governor-General states that "The Javanese" from Mataram cannot do without opium (Idem.).

43 F. de Haan, vol. 4, p. 14. 
from the harbor. Another Chinese trader received an iron canon to defend himself against pirates, etc. ${ }^{44}$

Probably the Chinese bought some opium as medicine in Malacca from Arabs and imported it to China, but I can find no proof of this. Among the Far Western traders, certainly the Portuguese imported opium for the first time into China via Macao in the same period; that is to say, sometimes they bought opium from the Dutch. In any case, it remained a Western product for the Chinese wherever they lived in Asia and whoever delivered the stuff. The maximum that could be achieved by Chinese merchants was copying the smuggling of the Dutch and Portuguese (a bit later also of the English) of goods into China, which was strongly opposed by the Chinese government. The Dutch were extradited to Formosa and had to leave China; the Portuguese could remain in Macao, clearly a matter of better diplomacy. In and around the Formosa settlement of the Dutch, which ended soon with their ignominious defeat, I could not discover any opium trading.

This Dutch-Chinese opium relationship (if any) must have changed in the 1660 s. The Dutch formalized their opium business in Bengal and Malabar and made it one of their major products for the first time. This was immediately important for the East Indies. It lead directly to war and an opium monopoly in Mataram (1678).

In his opium story De Haan reminds us that probably the first revenue farming in Batavia was established in January 1661 and concerned the tax on carved tobacco 'which within this city and its jurisdiction is consumed by the Chinese. 45 This tobacco was imported from China and later mixed with a little opium, which became madat. Apparently because also this opium was imported, this madat was prohibited ten years later (the socalled "Batavia jurisdiction"). This had nothing to do with 'a hygienic measure', as De Haan suggests. More relevant is his remark about the low price of madat for the slaves, which irritated their masters. But the main reason must have been that the expensive VOC opium was being undermined by so-called "smugglers".

A similar fear was the context for the opium prohibition among fishermen. However, the fishermen disappeared, and the Chinese opium farmers complained that their business was undermined (and could not pay taxes). Result: the measure was revoked (1672). The following cases demonstrate other aspects of a Dutch-Chinese opium relationship.

\footnotetext{
44 A. Meilink-Roelofsz, p. 150 reported 30-11-1727.

45 Idem, p. 16.
} 
In 1725 the Dutch sold to Chinese traders 'excluding amphioen and textiles for only 273,209 rixdollars and bought for 278,604 ... tea and noncoined gold ... ${ }^{46}$ Apparently this concerned a fleet of thirteen Chinese junks who came to Batavia, from which four hundred Chinese were allowed to stay. A year later the VOC publicly sold two lots of opium unfit for use with a poor profit of $13 \%$ and $8 \%$. The Chinese (it is unclear whether they were from China or Java) offered to buy 250 chests from these lots for 260 rixdollars each. This was refused as too cheap. ${ }^{47}$

One must suppose that, as mediators in Asian traffic, an elite among these "Overseas Chinese" became involved in this large-scale opium business, but only as servants of the Dutch, the opium suppliers. The growth of the ports attracted more Chinese junks trade. This happened even after the Dutch had consolidated their position in the East Indies archipelago: between 1680 and 1740 the arrivals of these junks in Batavia doubled from 10 to 20 per year.

However, De Haan gave a less optimistic view on the Dutch-Chinese opium relation when he described the dominant position of the high VOC official who covered all relationships with the Javanese in the areas south of Batavia, the Gecommitteerde tot en over de Zaken van den Inlander. This fully corrupt person

had the complete import of opium into [interior districts] ... sometimes including the import of salt. If he was willing he added a cattle business to this. He had a monopoly position and 'in avoiding all competition this must have led to an expensive market for the indigenous population ... the coffee [one was obliged to deliver in a near slavery relation] he paid in merchandise instead of cash money ... which was to the disadvantage of the Chinese who themselves liked a profit ...' etc. ${ }^{48}$

Also, the lower-ranking Dutch officials asked for bribes. How ambiguous the situation was is demonstrated in a report by Rolff (1786) about a per-

46 GM, VIII, p. 31 (August 1724).

47 Idem, p. 97.

48 F. de Haan, vol. 1, p. 302. See for this also F. Gaastra (2000), p. 14 who, however, did not refer to the opium mentioned by De Haan as the first item. Later (F. de Haan, vol. 4, p. 9) there is again a reference to the opium monopoly position of this 'Gecommitteerde', while apparently the salt-monopoly was exercised by a lower official, a Commander, 'notwithstanding the taking of a bribe from a Chinese'. Later Daendels was allowed to continue with the opium policy of this "Gecommitteerde" (see F. de Haan, idem, p. 22 ff.). After 1900 the colonial government also kept the opium and salt monopolies in one organization, the Opium- and Zoutregie (see ch. 19). At that time the same kind of coercion appeared as, for instance, a century earlier, as coffee was paid by the Dutch with salt (F. de Haan, idem.), etc. 
son equivalent to an inspector (with the German name Waltschedel) and his helper Weijkert. The former received 105 rixdollars (rixdaalders) from Chinese carpenters so that they could stay, but every year they first paid 200 rixdollars to Weijkert, who pocketed 95:

.. for this he allowed these Chinese to establish a shop (warong) to sell opium (afion) and all kinds of merchandise; this is very harmful because these Chinese accept from the garden personnel and the slaves stolen gardening tools in exchange for opium. ${ }^{49}$

The English or Portuguese never disappeared from the entire realm ranging from China to the Southeast Asian archipelago. The English even had a rather strong bridgehead, Bengkulu (Bencoolen, Benkulen) in West Sumatra, before they captured Singapore or Northern Borneo. From there they "smuggled" throughout the archipelago if they did not accept the Dutch rules. As the VOC power decreased after 1750, the English influence increased: now, war and opium were not very far apart.

The following description is illustrative for the Eastern part of Java and Bali (Strait), which was not yet wholly under control of the Dutch. Here the English energetically infiltrated:

One of the significant effects caused by the British presence in the region was the escalation in free trade or, as the Dutch preferred to call it, smokkelhandel or smuggling. The indigenous merchants from the surrounding areas were attracted by the opium and cotton which were distributed by the British at quite a low price, and offered the latter salt, rice and other foodstuffs in exchange. In fact, opium and textiles were also distributed by the Dutch, but the local traders preferred to buy them from the British merchants ... Among these merchants were Buginese and Mandarese who were already acquainted with the British merchants ... [in] Bengkulu ... now ..their voyage was shortened considerably, and they could easily pick up the opium with only a minor risk. ${ }^{50}$

Around the Bali Strait representatives of the Javanese elite and Chinese merchants were also involved in the opium trade. Sometimes they were caught by the Dutch, including their opium cargo, which always appeared to be of English origin. This "free trade" did not concern large consignments of opium: sometimes one and a half chests, another 200 pounds including weapons, or twenty catty of British opium. A Dutch investiga-

\footnotetext{
49 F. de Haan, vol. 2, p. 614.

50 S. Margana (2007), p. $42 \mathrm{ff}$.
} 
tion into this matter revealed even that "the "legal" opium was used as pretext for the "illegal" one. ${ }^{51}$

Anyway, the Dutch did not hesitate very long before waging a fullfledged opium war in 1768 in Java's Oosthoek (Eastern Salient or Blambangan), using quarrels with neighboring Bali as a pretext to conquer the area. Although quickly won, this war triggered new depopulations, massacres, ethnic cleansings, one revolt after another, religious antagonisms until long after Raffles' time in Java. In this turmoil Chinese merchants also got caught in the cross-fire of their former colleagues, the Buginese merchants. Other Chinese who happened to become involved in the political leadership had to pay with their life. This was the chaos in which a fundamental transformation took place, which was characterized by the definitive destruction of the VOC and its monopolistic trade culture.

51 Idem, p. 45. 